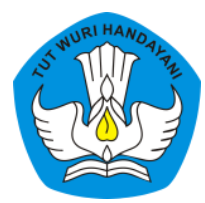

Page: 621-640

\title{
Pengembangan Modul Materi Cahaya Berbasis PBL4C Untuk Meningkatkan Keterampilan Berpikir Kritis Siswa Sekolah Penengah Pertama
}

\author{
A'irin Nurwidyastuty \\ Sekolah Menengah Pertama Negeri 1 Kraksaan Probolinggo \\ Contributor Email: airinpotter@gmail.com
}

Article Url: http://ojsdikdas.kemdikbud.go.id/index.php/didaktika/article/view/121

\begin{abstract}
Teaching and learning activities must be supported by teaching material that raises contextual problems thereby improving students' thinking processes. The purpose of this study is to describe the process and results of module development, the objectives and competencies to be achieved, the strengths and weaknesses of the module, and the improvement of critical thinking skills after using the module. Module development by using the $4 D$ model that is define, design, develop and assess produce PBL4C (Problem Based Learning the 4 Core Areas) modules. The material validation score is 3.31 , the design validation score is 3.51 , the language validation score is 3.47 which means that the module is stated valid. Modules are also developed in the Android application so students can study anywhere, anytime, with anyone. PBL4C is PBL which is an integration of multi-disciplinary knowledge, multi-dimensional skills, correct thoughts and universal harmonious values. Based on research data that is normality test, amounting to 0.131 with Asymp. Sig. (2-tailed) of 0.179 with a value of $p>0.05$, so it can be concluded that the data are normally distributed. Homogeneity test results stated the value of $F=1.072$ and $p$ value $>0.05$ (sig. (0.422)> 0.05) means the distribution of homogeneous data. Based on hypothesis testing using $T$ test $p$ value $(.000)<0.05 . H_{0}$ is rejected and $H_{1}$ is accepted which means the module can improve students' critical thinking skills.
\end{abstract}

Keywords: Module; PBL4C; Critical Thinking Skill 


\begin{abstract}
Abstrak
Pembelajaran di kelas harus didukung bahan ajar yang memunculkan permasalahan kontekstual sehingga meningkatkan proses berpikir siswa. Tujuan penelitian ini adalah untuk mendeskripsikan proses dan hasil pengembangan modul, tujuan dan kompetensi yang ingin dicapai, kelebihan dan kekurangan modul, serta peningkatan keterampilan berpikir kritis setelah menggunakan modul. Pengembangan modul dengan menggunakan model 4D yaitu define, design, develop dan dessiminate menghasilkan modul PBL4C (Problem Based-Learning the 4 Core Areas). Skor hasil validasi materi modul adalah 3,31, skor validasi desain modul adalah 3,51, skor validasi bahasa modul adalah 3,47 yang berarti modul dapat dikatakan valid. Modul juga dikembangkan dalam aplikasi android sehingga siswa dapat belajar dimana saja, kapan saja, bersama siapa saja. PBL4C merupakan PBL yang merupakan integrasi dari pengetahuan multi disiplin, keterampilan multi dimensi, pikiran yang tepat dan nilai harmonis universal. Berdasarkan data penelitian yaitu uji normalitas, sebesar 0,131 dengan Asymp. Sig. (2-tailed) sebesar 0,179 dengan nilai p>0,05, sehingga dapat disimpulkan bahwa data berdistribusi normal. Hasil uji homogenitas menyatakan nilai $F=1.072$ dan nilai $p>0.05$ (sig. (0.422)>0.05) berarti sebaran data homogen. Berdasarkan uji hipotesis menggunakan T test nilai $p(.000)<0.05$. $H_{0}$ ditolak dan $H_{1}$ diterima yang berarti modul dapat meningkatkan keterampilan berpikir kritis siswa.
\end{abstract}

Keywords: Modul; PBL4C; Keterampilan Berpikir Kritis

\title{
A. Pendahuluan
}

Pendidikan dalam revolusi keempat 4.0 adalah pintu terbuka yang memberikan energi bagi masyarakat untuk mengubah keadaan. Revolusi industri keempat mendorong fokus lingkungan pembelajaran dari penugasan menjadi kualitas manusia (Hussin, 2018:316). Selain itu, abad 21 menuntut adanya perkembangan pesat dalam bidang sains dan teknologi. Berkaitan dengan kemajuan sains dan teknologi yang signifikan dan cepat ini, para pemangku kepentingan di bidang pendidikan harus mampu mengantisipasinya agar mereka dapat mempersiapkan generasi masa depan yang siap dalam menghadapi abad ke-21 (Fuad, 2017:102).

Kondisi pembelajaran di kelas yang mendukung keterampilan berpikir kritis siswa masih memerlukan perbaikan dan penyempurnaan. Guru terkadang tidak memberikan permasalahan dalam kehidupan sehari-hari. Penggunaan bahan ajar yang tidak kontekstual mengakibatkan 
siswa kesulitan mengkonstruk pengetahuan mereka sendiri. Hal ini juga mengakibatkan keterampilan berpikir kritis siswa tidak berkembang. Keterampilan berpikir kritis sangat diperlukan dalam penyelesaian masalah yang kompleks sehingga siswa membutuhkan kemampuan untuk menganalisis, mengevaluasi, dan menciptakan (Mohd Tahjudin \& Chinnappan, 2016:200).

Berdasarkan penelitian awal berupa angket yang dilakukan pada siswa SMPN 1 Kraksaan kelas VIII pada tanggal 16 Januari 2019 didapatkan data $85 \%$ siswa menyatakan bahwa materi pembelajaran IPA yang dianggap paling susah adalah materi cahaya, baik dari segi kekomplekan materi dan daya dukung. Berdasarkan data, alasan mereka memilih materi cahaya sebagai materi yang paling sulit adalah $65 \%$ siswa tidak paham dengan buku siswa yang selama ini dipelajari, 25\% siswa menyatakan tidak paham dengan materi yang disampaikan oleh guru. Sedangkan selebihnya menyatakan karena faktor lain yaitu kurang minat belajar, sulit dan tidak ada lembar kerja untuk berlatih soal. Guru juga tidak mengeksplore materi pembelajaran dan siswa tidak diberikan lembar kerja yang memicu siswa untuk berpikir kritis. Guru biasanya hanya mengajarkan materi dengan memberikan catatan di papan tulis dan mengerjakan soal pilihan ganda yang ada di buku siswa, dimana soal masih belum kontekstual dalam kehidupan sehari-hari.

Model pembelajaran yang dianggap meningkatkan keterampilan sosial terutama keterampilan berpikir kritis adalah problem based learning (Pebriana, 2017:112). Sebagai model pembelajaran, problem based learning memiliki beberapa aspek, atau strategi, yang mendukung keunggulan model tersebut. Problem based learning fokus pada pembelajaran siswa secara langsung daripada kegiatan menghafal fakta. Hal ini juga memicu siswa untuk menggunakan keterampilan berpikir tingkat tinggi, yang mengharuskan siswa untuk menganalisis, membuat, mempertahankan atau mengevaluasi. Siswa aktif secara sosial dan belajar untuk bekerja sebagai bagian dari kelompok, mengajukan dan menjawab pertanyaan dan mendukung pemikiran orang lain. Hal ini menginspirasi SEAMEO RECSAM (South East Asian Ministers of Education Organization-Regional 
Centre for Science and Mathematics) memperkenalkan Problem-Based Learning the 4 Core Areas (PBL4C) pada tahun 2008. The 4 core areas merupakan gabungan antara pengetahuan multi disiplin, keterampilan multi dimensi, pikiran yang tepat dan nilai harmonis universal.

Rumusan masalah yang dapat diajukan dalam penelitian ini adalah bagaimana pengembangan modul berbasis PBL4C untuk materi cahaya, bagaimana tujuan yang ingin dicapai dalam penggunaan modul PBL4C materi cahaya, bagaimana kelebihan dan kekurangan modul berbasis PBL4C untuk materi cahaya, dan apakah penerapan modul berbasis PBL4C dapat meningkatkan keterampilan berpikir kritis siswa pada materi cahaya.

Tujuan penelitian ini adalah untuk mendeskripsikan proses dan hasil pengembangan modul berbasis PBL4C, mendeskripsikan tujuan dan kompetensi yang ingin dicapai dalam penggunaan modul PBL4C materi cahaya, mendeskripsikan kelebihan dan kekurangan modul berbasis PBL4C untuk materi cahaya, mengetahui peningkatan keterampilan berpikir kritis setelah menggunakan modul berbasis PBL4C pada materi cahaya.

Manfaat yang ingin dicapai dalam penelitian ini bagi guru adalah meningkatkan kemampuan dalam melakukan penelitian dan mengembangkan modul pembelajaran, mempunyai karya inovasi pembelajaran yang bermanfaat dalam dunia pendidikan. Bagi siswa untuk memberikan penyelesaian untuk lebih memahami materi cahaya dan meningkatkan keterampilan berpikir kritis siswa. Bagi sekolah dapat menambah variasi bahan ajar dalam pembelajaran di kelas. Bagi masyarakat dapat membantu menyiapkan generasi yang siap menghadapi abad 21 karena terjadi peningkatan keterampilan berpikir kritis.

\section{B. Metode}

Jenis penelitian yang digunakan untuk mengembangkan modul ini adalah memodifikasi model 4D (Four D model) oleh Thiagarajan dan Sammel. Model ini dipilih karena memiliki langkah-langkah yang sistematis yang digunakan secara prosedural. Dalam buku Thiagarajan 
yang berjudul Instructional for Training Teacher of Expectional Children dijelaskan bagaimana cara mengembangkan bahan ajar dan bukan rancangan pengajarannya. Tahapan model pengembangan ini adalah define atau pendefinisian, design atau perancangan, develop atau pengembangan, dan desseminate atau penyebaran.

Tahapan desain/design adalah menyiapkan prototype dari modul pembelajaran materi cahaya dengan menggunakan model PBL4C. Tahap perancangan pada tahapan desain ini dikembangkan kedalam tiga tahapan sesuai dengan komponen modul yaitu tahapan pendahuluan, tahapan pembelajaran dan tahapan evaluasi. Setelah draft awal terbentuk yaitu RPP dan modul tersusun maka dilanjutkan dengan tahapan pengembangan/develop. Tahapan ini adalah tahapan akhir sebelum dilakukan tahapan penyebaran. Tahapan pengembangan disesuaikan dengan tahapan perancangan yaitu terdiri dari tiga tahapan yaitu pengembangan pendahuluan, pengembangan pembelajaran, dan pengembangan evaluasi.

Tahapan selanjutnya adalah validasi ahli. Validasi dilakukan oleh dua orang ahli bahan ajar pembelajaran dan sering membuat bahan ajar. Yang pertama adalah ahli isi/materi, validator kedua adalah ahli desain yaitu. Saran perbaikan yang diterima dari validator 1 ahli isi yaitu: 1) tambahkan materi teknologi cahaya dalam kehidupan sehari-hari seperti laser; 2) tambahkan soal pilihan ganda pada bagian evaluasi, 3) tambahkan tahapan PBL4C pada bagian awal modul. Saran perbaikan dari validator kedua yaitu 1) perlu ditambahkan animasi/gambar pada setiap materi pada komponen pembelajaran; 2) modul sangat bagus, perlu dikembangkan ke dalam aplikasi android.

Tahapan selanjutnya yaitu dilakukan uji coba terbatas. Uji coba terbatas ini dilakukan pada siswa kelas VIIIA SMPN 1 Kraksaan. Hasil revisi dari validasi ahli dilakukan sebagai bahan untuk melakukan uji coba terbatas. Dari hasil pretes dan postes akan dilakukan hasil uji prasyarat yaitu uji normal dan uji homogen. Untuk mengetahui apakah ada pengaruh pemberian modul PBL4C materi cahaya terhadap keterampilan berpikir kritis siswa dilakukan $\mathrm{T}$ test. 


\section{Hasil dan Pembahasan}

Aplikasi praktis pembelajaran modul PBL4C ini menggunakan tahapan PBL dalam proses pembelajaran. PBL dapat dilakukan dengan tahapan: (1) orientasi siswa pada permasalahan; (2) mengorganisasikan siswa dalam proses pembelajaran; (3) membimbing penyelidikan individual maupun kelompok; (4) mengembangkan dan mengkomunikasikan hasil karya penyelidikan; (5) menganalisis dan mengevaluasi proses pemecahan masalah. Proses pembelajaran ini menggunakan modul PBL4C sebagai bahan ajar ini yang dimulai dari komponen pendahuluan, pembelajaran dan kemudian tahapan evaluasi. Proses ini sudah berkesesuaian dengan tahapan pembelajaran. Pada komponen pembelajaran dimana setelah uraian materi, siswa sudah dihadapkan pada permasalahan context problem yang diberikan. Ada 4 tipe permasalahan context problem yang disajikan dalam modul ini. Guru sebagai fasilitator dapat memilih tipe mana yang digunakan atau dapat pula menggunakan keseluruhan tipe dengan membagi antara kelompok satu dengan yang lain.

Context problem disajikan dengan tahapan tambahan yaitu skenario 1, skenario 2, dan ada 1 tipe yang dikembangkan hingga skenario 3. Masing-masing berada pada lembar jawaban yang berbeda. Siswa dapat berkreasi dengan menambahkan gambar/ilustrasi yang berhubungan dengan penjelasan permasalahan yang disajikan pada context problem, skenario 1, skenario 2 atau skenario 3. Ada beberapa permasalahan yang disajikan untuk membuat desain.

Tabel 1. Tipe 1

\footnotetext{
CONTEXT PROBLEM

Polusi cahaya adalah salah satu jenis polusi yang jarang diketahui banyak orang. Polusi ini bisa didefinisikan sebagai dampak buruk akibat cahaya buatan manusia yang berasal dari intensitas cahaya yang terlau besar terutama yang menuju ke arah langit. Akibat dari polusi ini berakibat pada lingkungan, seperti penelitian astronomi, sumber daya energi, juga berdampak bagi tumbuhan, hewan dan manusia. Bagi beberapa orang yang mengetahui polusi cahaya bersikap apatis dan tidak peduli bahkan tidak melakukan langkah apa pun untuk mencegahnya. Bahkan beberapa negara mengalami kerugian dari polusi cahaya hingga satu milliar dolar setiap tahunnya.

SKENARIO 1

Polusi cahaya sendiri banyak disebabkan oleh pihak industri. Polusi cahaya banyak berasal dari pencahayaan eksterior (luar gedung) dan interior (dalam gedung). Selain itu polusi cahaya juga banyak berasal dari papan iklan, properti komersial, lampu jalan, lampu stadion dan gedung gedung. Wilayah yang memiliki industrialisasi besar dengan tingkat kepadatan yang tinggi akan mengalami polusi cahaya yang parah. Misalnya negara-negara di Amerika Utara, Jepang, Eropa,
} 
Pengembangan Modul Materi Cahaya Berbasis PBL4C Untuk Meningkatkan Keterampilan

A'irin Nurwidyastuty

beberapa kota di Timur Tengah, juga Kairo. Beberapa pekerjaan masa depan yang cukup berkembang adalah pekerjaan desain interior. Jika kelak kalian bekerja di bagian tersebut, coba buatlah desain bagaimana letak pencahayaan bangunan, kantor ataupun pabrik untuk mengurangi polusi cahaya

\section{SKENARIO 2}

Banyak sedikitnya cahaya yang digunakan di rumah kalian akan berdampak pada banyaknya tagihan listrik yang dibayarkan tiap bulan. Jika rumah kalian memiliki daya $900 \mathrm{~W}$ dan $1300 \mathrm{~W}$, buatkan rincian berapa banyak lampu penerangan yang akan kalian gunakan dan jenis rangkaian apa yang digunakan. Desain rumah dan kamar sesuaikan dengan kondisi rumahmu

\section{SKENARIO 3}

Di beberapa negara maju seperti Amerika dan Eropa melakukan beberapa tindakan pencegahan untuk mengurangi polusi cahaya. Tindakan yang diambil ada yang berkaitan dengan tagihan energi listrik dan peduli lingkungan. Jika kalian sebagai pemangku kebijakan baik di tingkat kabupaten, provinsi bahkan nasional, kebijakan apakah yang ingin kalian terapkan dalam usaha mengurangi polusi cahaya dan jelaskan alasannya. Kaitkan juga kebijakan tersebut dengan kegiatan yang bersifat ramah lingkungan

Tabel 2. Tipe 2

\section{CONTEXT PROBLEM}

Banyak orang yang sudah mengetahui manfaat sinar laser dalam kehidupan sehari-hari. Laser sendiri kepanjangan dari Light Amplification by Stimulated Emission of Radiation. Laser memancarkan radiasi elektromagnetik, dalam bentuk cahaya yang dapat dilihat oleh mata maupun tidak dapat dilihat oleh mata melalui pancaran terstimulasi. Laser terjadi karena efek dari mekanika kuantum. Pancaran laser akan memancarkan foton dalam pancaran koheren berupa sinar tunggal.

\section{SKENARIO 1}

Cacat mata ada beberapa macam diantaranya rabun jauh, rabun dekat, astigmatisma. Pengobatannya pun juga beragam ada yang menggunakan kacamata berlensa, operasi bedah mata menggunakan laser yang dikenal dengan istilah LASIK, dan terapi pengobatan. Bagaimana proses LASIK dapat bekerja untuk pengobatan mata?

\section{SKENARIO 2}

Teknologi laser juga dapat dimanfaatkan untuk menghilangkan tato, tanda lahir bahkan dapat memotong objek. Buatlah desain bagaimana laser dapat memotong sebuah benda. Bayangkan juga bagaimana hidupmu jika tidak terdapat laser, apa yang akan terjadi?

\section{Tabel 3. Tipe 3}

\section{CONTEXT PROBLEM}

Pada liburan sekolah, keluargamu berkunjung ke rumah kakek nenekmu di pedesaan. Disana sangat jauh dari keramaian kota dan transportasi umum. Tiba-tiba kakekmu sakit, sehingga kedua orangtuamu dan nenekmu mengantarkan kakekmu ke rumah sakit. Kamu ditinggal sendiri di rumah bersama kedua adikmu dan kamu bertanggung jawab atas mereka.

\section{SKENARIO 1}

Kamu ditinggal sendiri di rumah bersama kedua adikmu dengan uang senilai Rp. 200.000. Tiba waktunya makan siang, kamu harus menyiapkan nasi dan lauk pauk untuk makan kedua adikmu. Dirumah sudah tersedia beras tetapi tidak terdapat lauk pauk. Untuk pergi kepasar sangat jauh dan tidak ada angkutan umum. Satu-satunya yang ada dalam benakmu adalah kolam ikan yang cukup dalam disamping rumahmu. Kamu mencoba mencari pancing atau kasa pengambil ikan kesekeliling rumah tetapi tidak ditemukan. Kamu hanya menemukan tombak di samping meja makan. Apa yang kamu lakukan untuk persiapan makan siangmu? Akankah kamu akan menggunakan tombak untuk menangkap ikan? Berikan alasanmu beserta bagaimana cara menangkap ikan menggunakan tombak padahal kamu tidak pernah menggunakannya untuk menangkap ikan?

\section{SKENARIO 2}

Tanpa diduga-duga ada tetangga sebelah datang kerumahmu meminta bantuan padamu. Dia 
hendak menjual perhiasan berlian untuk biaya menjenguk anaknya di Jakarta. Dia memohon padamu untuk mau membelinya dengan harga murah senilai Rp. 200.000. jika hendak membeli ditoko mungkin senilai Rp.800.000, kata tetangga sebelah. Apa yang akan kamu lakukan? Apakah kamu mempercayai perkataan tetanggamu dan membeli perhiasan berlian tersebut? Berikan penjelasan yang logis berkaitan dengan konsep sifat cahaya!

\section{Tabel 4. Tipe 4}

\section{CONTEXT PROBLEM}

Air sangat dibutuhkan dalam kehidupan manusia. Air memiliki banyak manfaat, diantaranya minum, mandi, masak, mencuci, dll. Sayangnya, jumlah air yang dapat dikonsumsi oleh manusia jumlahnya sangat sedikit. Sebagian besar permukaan bumi justru tertutupi oleh air laut.

\section{SKENARIO 1}

Air laut tidak dapat dikonsumsi oleh manusia karena kandungan garamnya. Saat ini ada metode modern yang digunakan para ilmuwan untuk memindahkan garam dan mengubah air laut menjadi air siap minum. Sayangnya proses ini sangat rumit. Sains dan teknologi terus berkembang. Sebuah tim dari salah satu sekolah menengah menemukan teknologi sains membuat desain dan konstruksi dari seperangkat lensa raksasa dan prisma untuk mengatasi masalah tersebut. Jika kamu adalah tim tersebut, buatlah desain konstruksinya dan jelaskan prinsip yang terjadi didalamnya dan kaitkan dengan materi cahaya yang sudah kamu kuasai.

\section{SKENARIO 2}

Kamu sudah membuat desain dan konstruksi dari pembangunan teknologi tersebut. Dari desain tersebut didapatkan air murni yang siap diminum. Apakah ini efektif? Adakah keuntungan dan kerugian dari desain yang kamu buat?

Data keterampilan berpikir kritis siswa merupakan data siswa dalam menjawab instrumen tes keterampilan berpikir kritis siswa. Uji coba dilakukan pada kelas VIII A sebanyak 32 siswa dimulai pada tanggal 27 Maret 2019 untuk pertemuan 1 dan pengambilan data pretes. Pertemuan kedua pada tanggal 28 Maret 2019. Pertemuan ketiga pada tanggal 3 April 2019, pertemuan keempat pada tanggal 4 April 2019, pertemuan kelima pada tanggal 10 April 2019 dan pengambilan data postes pada 11 April 2019.

Statistik deskriptif data pretes keterampilan berpikir kritis siswa dapat dilihat pada tabel 5 .

Tabel 5. Statistik Deskriptif Pretest Keterampilan Berpikir Kritis Siswa

\begin{tabular}{ccccccccc}
\hline Mean & Median & Varian & $\begin{array}{c}\text { Std } \\
\text { Deviasi }\end{array}$ & Minimum & Maximum & Range & Skewness & Kurtosis \\
\hline 67,5 & 68 & 79,484 & 8,915 & 46 & 82 & 36 & -.488 & -.229 \\
\hline
\end{tabular}

\section{Deskripsi Hasil Uji Prasyarat}

Berdasarkan data kemampuan awal, keterampilan berpikir kritis sebelum digunakan untuk pembuktian hipotesis harus dilakukan uji prasyarat analisis untuk mengetahui apakah data tersebut berdistribusi 
normal atau tidak. Uji prasyarat analisis ini meliputi uji normalitas dan uji homogenitas dapat dijabarkan sebagai berikut.

\section{Uji Normalitas}

Dalam penelitian ini, uji normalitas data keterampilan berpikir kritis dilakukan dengan bantuan SPSS-26 for windows. Hasil uji normalitas kemampuan awal keterampilan berpikir kritis dapat dijabarkan dalam tabel 6.

Tabel 6. Deskripsi Hasil Uji Normalitas Keterampilan Berpikir Kritis

\begin{tabular}{lc}
\hline & Keterampilan Berpikir Kritis \\
\hline Kolmogorov-Smirnov Z & 0,131 \\
\hline Asymp. Sig. (2-tailed) & 0,179 \\
\hline Shapiro Wilk & 0,961 \\
\hline Asymp. Sig. (2-tailed) & 0,282 \\
\hline Kesimpulan & Normal \\
\hline
\end{tabular}

Dari tabel 6 diperoleh nilai Kolmogorov-Smirnov untuk tes keterampilan berpikir kritis sebesar 0,131 dengan Asymp. Sig. (2-tailed) sebesar 0,179 dengan nilai $p>0,05$, sehingga dapat disimpulkan bahwa data yang dianalisis tersebut adalah data yang berdistribusi normal. Grafik normal plot dapat dilihat pada gambar berikut.

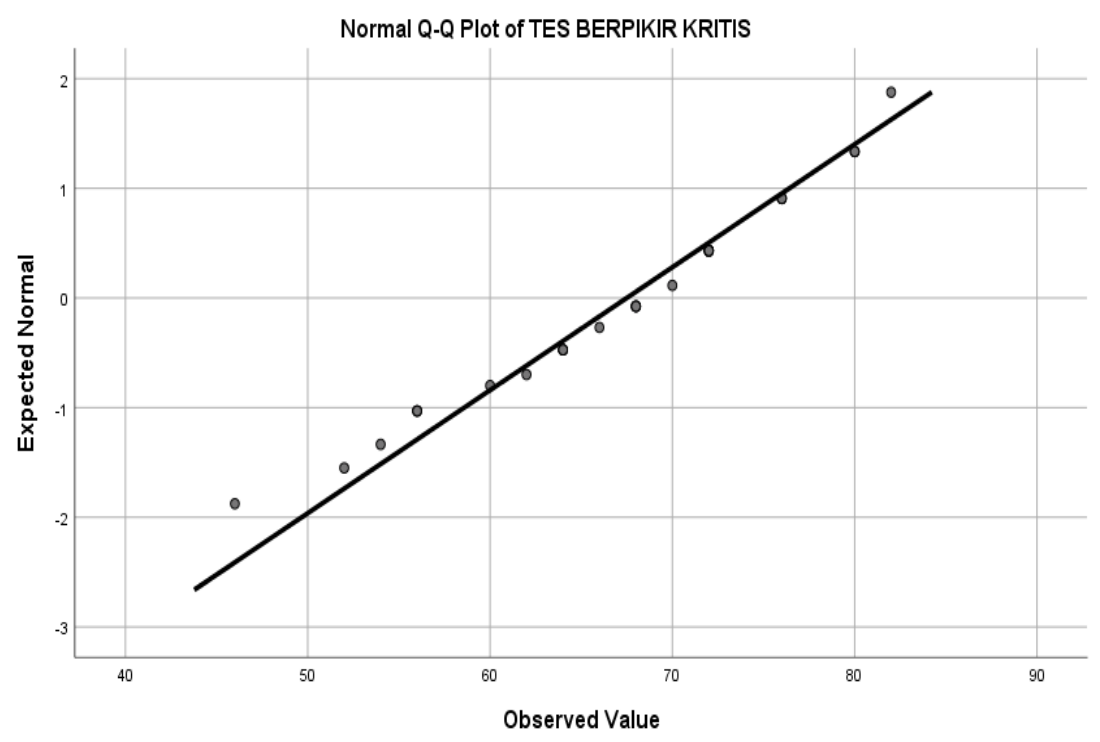

Gambar 1. Grafik Q-Q Plot Normalitas Data Keterampilan Berpikir Kritis 


\section{Uji Homogenitas}

Tabel 7: Data Hasil Uji Homogenitas Data Keterampilan Berpikir Kritis antara pretes dan Postest

Levene's Test of Equality of Error Variances ${ }^{a}$

Dependent Variable:keterampilan berpikir kritis

\begin{tabular}{cccc}
\hline $\mathrm{F}$ & $\mathrm{df1}$ & $\mathrm{df2}$ & Sig. \\
\hline 1.072 & 8 & 19 & 0.422 \\
\hline
\end{tabular}

Dalam penelitian ini, uji homogenitas data keterampilan berpikir kritis dilakukan dengan bantuan SPSS-26 for windows. Uji homogenitas dilakukan untuk mengetahui apakah data dari dua kelompok data yang diteliti homogen atau tidak. Uji homogenitas dilakukan pada variabel data hasil keterampilan berpikir kritis antara pretes dan postes. Hasil uji homogenitas tiap variabel terangkum pada tabel 7 .

Uji hasil uji homogenitas dari data dua kelompok terlihat bahwa nilai $\mathrm{F}=1.072$ dan nilai $\mathrm{p}>0.05$ (sig. (0.422) $>0.05$ ) ternyata tidak signifikan, sehingga mengandung arti bahwa sebaran data adalah homogen.

\section{Deskripsi Uji Hipotesis}

Uji hipotesis penelitian dilakukan dengan menguji ada tidaknya pengaruh modul PBL4C materi cahaya terhadap keterampilan berpikir kritis siwa. dengan bantuan SPSS 26 for Windows. Paired sample $t$ test merupakan uji beda dua sampel berpasangan. Sampel berpasangan merupakan subjek yang sama namun mengalami perlakuan yang berbeda. Kriteria pengujian jika menghasilkan angka signifikansi kurang dari 0,05 maka hipotesis nol ditolak dan dalam hal lain hipotesis diterima.

Pertanyaan penelitian: apakah terdapat perbedaan yang signifikan antara rata-rata nilai pretest dan posttest siswa yang diberlakukan menggunakan modul PBL4C?

$\mathrm{H}_{0}$ : Tidak terdapat perbedaan antara rata-rata nilai pretest dan posttest siswa

$\mathrm{H}_{1}$ : Terdapat perbedaan antara rata-rata nilai pretes dan postes siswa 
Tabel 8. Data Hasil Paired Sample T-test

\begin{tabular}{|c|c|c|c|c|c|}
\hline \multicolumn{6}{|c|}{ Paired Samples Statistics } \\
\hline \multirow{2}{*}{ Pair 1 } & Mean & N & Std. Deviation & Std. Error Mean \\
\cline { 2 - 6 } & PRETES & 67.5000 & 32 & 8.91537 & 1.57603 \\
\hline \multicolumn{7}{|c|}{ Paired Samples Correlations } \\
\hline POSTES & 92.0938 & 3.20429 \\
\hline Pair 1 & \multicolumn{2}{|c|}{ PRETES \& POSTES } & N & Correlation & Sig. \\
\hline
\end{tabular}

Dari hasil tabel 8 menunjukkan bahwa nilai $\mathrm{p}(.000)<0.05$. Dengan kriteria tersebut, maka $\mathrm{H}_{0}$ ditolak dan $\mathrm{H}_{1}$ diterima. Dengan kata lain hasil uji menunjukkan bahwa terdapat perbedaan yang signifikan antara keterampilan berpikir kritis siswa dengan pemberian modul PBLAC materi cahaya. Pemberian modul PBL4C materi cahaya dapat meningkatkan hasil keterampilan berpikir kritis siswa.

\section{Pengembangan Modul Berbasis PBL4C}

\section{Tahap pendefinisian (define)}

Tahap pendefinisian merupakan tahapan awal dalam pengembangan, adapun kegiatan pada tahapan ini adalah sebagai berikut.

a. Analisis akhir terdepan

Kegiatan analisis akhir terdepan dilakukan untuk menetapkan masalah dasar yang diperlukan dalam pengembangan modul dengan cara melakukan diskusi dengan guru IPA. Pada tahap ini dilakukan telaah terhadap kurikulum IPA kurikulum 2013. Berbagai teori belajar yang relevan dan tantangan serta tuntutan masa depan, sehingga diperoleh deskripsi pola pembelajaran yang dianggap paling sesuai. Jadi dalam penelitian ini tidak mengembangkan materi pembelajaran baru, tetapi menggunakan materi yang telah ada pada kurikulum 2013 untuk dikembangkan menggunakan tahapan problem based learning dimana dalam proses pemberian permasalahan disajikan melalui PBL4C yaitu context problem, skenario 1, skenario 2, dan skenario 3 .

b. Analisis Siswa

Analisis karakteristik siswa kelas VIII SMPN 1 Kraksaan tahun ajaran 2018/2019, meliputi latar belakang kemampuan akademik untuk mata 
pelajaran prasyarat yaitu getaran dan gelombang. Kemampuan kognitif dan latar belakang kemampuan akademik siswa untuk materi prasyarat getaran dan gelombang secara klasikal ketuntasan mencapai $87 \%$. Dapat dikatakan bahwa kemampuan akademik prasyarat cahaya dikatakan cukup baik.

c. Analisis Konsep

Pada tahap ini mengidentifikasi konsep-konsep materi cahaya yang akan diajarkan dan menyusunnya secara sistematis, serta mengaitkan satu konsep dengan konsep yang lainnya sehingga membentuk sebuah peta konsep.

d. Analisis Tugas

Analisis tugas ini berguna untuk mengembangkan kegiatan belajar di dalam modul yang disesuaikan dengan PBLAC. Kegiatan yang dilakukan pada tahap ini adalah melakukan identifikasi berbagai keterampilan yang disesuaikan dengan pencapaian indikator pembelajaran.

e. Spesifikasi Indikator Pembelajaran

Penyusunan tujuan pembelajaran yang didasarkan pada kompetensi dasar dan indikator pembelajaran.

\section{Tahap Perancangan (design)}

Tahap ini bertujuan merancang modul berbasis PBL4C materi cahaya. Hasil dari tahap perancangan (design) disebut draft-1. Bahan ajar yang dihasilkan adalah modul berbasis PBL4C. Adapun kegiatan pada tahap ini sebagai berikut (a) rancangan pendahuluan, (b) rancangan pembelajaran, dan (c) rancangan evaluasi.

\section{Tahap Pengembangan (develop)}

Tahap pengembangan ini merupakan pengembangan dari rancangan yang telah dibuat pada tahap perancangan (design) yang terdiri dari 3 bagian yaitu (a) pendahuluan, (b) pembelajaran, dan (c) evaluasi. 


\section{Hasil Validasi}

Modul PBLAC yang dihasilkan dikonsultasikan untuk mendapatkan masukan, perbaikan, dan saran, kemudian divalidasi oleh dua orang ahli. Validator menilai modul PBL4C berdasarkan lembar validasi. Hasil validasi modul PBL4C selengkapnya diuraikan sebagai berikut.

\section{Hasil Validasi Materi Modul}

Lembar validasi modul memuat tiga aspek, yaitu (1) isi modul, (2) bahasa, tulisan dan tampilan, (3) manfaat modul. Berdasarkan hasil validasi ahli terhadap modul, diperoleh skor rata-rata keseluruhan aspek adalah 3,31. Menurut kriteria kevalidan yang telah ditetapkan, maka prototype modul dapat dikatakan valid.

\section{Hasil Validasi Desain Modul}

Lembar validasi bahan ajar memuat tiga aspek, yaitu (1) ukuran modul, (2) desain cover, (3) ilustrasi cover, (4) desain isi modul, (5) tipografi cover dan isi modul, (6) tipografi isi modul, (7) ilustrasi dan gambar dalam modul, dan (8) penggunaan warna. Berdasarkan hasil validasi ahli terhadap modul, diperoleh skor rata-rata keseluruhan aspek adalah 3,51. Menurut kriteria kevalidan yang telah ditetapkan, maka prototipe modul dapat dikatakan valid.

\section{Hasil Validasi Bahasa Modul}

Lembar validasi modul memuat tiga aspek, yaitu (1) kelugasan, (2) kekomunikatifan, (3) kedialogisan dan keinteraktifan, (4) kesesuaian dengan perkembangan peserta didik, (5) kesesuaian dengan kaidah Bahasa Indonesia, dan (6) penggunaan istilah, simbol atau ikon. Berdasarkan hasil validasi ahli terhadap modul, diperoleh skor rata-rata keseluruhan aspek adalah 3,47. Menurut kriteria kevalidan yang telah ditetapkan, maka bahasa dalam modul dapat dikatakan valid. Hal ini berarti modul layak digunakan. 


\section{Tujuan yang Ingin Dicapai dalam Penggunaan Modul Berbasis PBL4C}

PBL4C bertujuan untuk mengoptimalkan pertumbuhan siswa dalam pengetahuan dan pemahaman, meningkatkan proses berpikir, meningkatkan kinerja kelompok dan mendorong belajar aktif. Siswa dalam PBL4C akan menjadi pembelajar aktif, berlatih kemampuan kepemimpinan, menikmati pembelajaran sains, meningkatkan kemampuan pengambilan keputusan, dan kemampuan memecahkan masalah. Hal ini juga menandakan bahwa proses PBL4C menjanjikan keuntungan yang besar bagi siswa (Preechaporn, Tat, Kin, \& Kheong, 2011:8).

Dalam pelaksanaan PBL4C, kegiatan kelas yang dibangun yaitu permasalahan kontekstual. Masalah yang digunakan berupa stimulus bagi siswa untuk memulai proses pembelajaran. Guru harus membimbing dan mendukung penyelidikan siswa. Siswa diberdayakan untuk mengambil peran tanggung jawab dalam pembelajaran. Siswa harus mengambil inisiatif untuk menemukan dan selama pembelajaran berlangsung harus mengaplikasikan pada permasalahan dengan melakukan reanalysis dan resolution. Siswa akan mencari penyebab dari permasalahan dan mencari tahu apa yang sudah diketahui dan apa yang harus diketahui agar dapat memecahkan masalah. Hal ini merupakan proses berpikir aktif dan reflektif.

Keterampilan berpikir kritis adalah keterampilan berpikir dalam pembelajaran yang melibatkan proses kognitif dalam berpikir reflektif untuk memecahkan masalah yang dihadapi. Indikator yang digunakan menurut Ennis ada 5 indikator utama yaitu bagaimana siswa dapat memberikan penjelasan secara sederhana, bagaimana siswa dapat membangun keterampilan dasar, bagaimana siswa dapat memberikan penjelasan lebih lanjut, bagaimana siswa dapat menyusun strategi dan taktik dalam penyelesaian masalah, dan bagaimana siswa dapat membuat kesimpulan. 

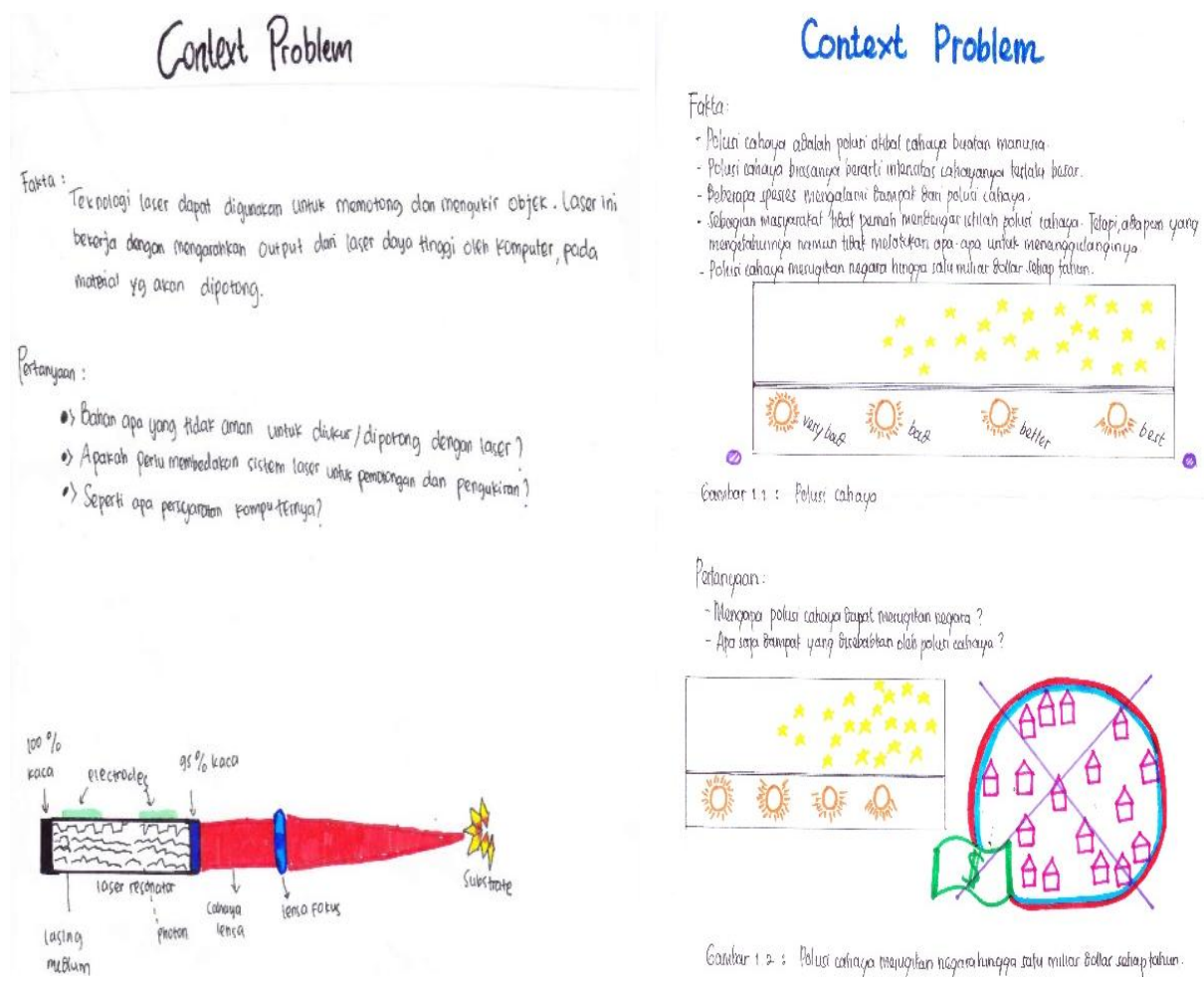

Gambar 2. Apa yang Kamu Tahu tentang Context Problem

Siswa diminta mengajukan fakta dan pertanyaan berdasarkan konteks problem yang disajikan. Bagian ini dikatakan juga apa yang kamu tahu. Fakta-fakta/informasi datang dari analisis kelompok dari apa yang diketahui. Analisis ini mencakup apa yang sebenarnya yang diketahui dan apa kekuatan dan kemampuan yang dimiliki oleh masing-masing anggota tim. Catatan masukan dari semua anggota kelompok, tidak peduli seberapa aneh kemungkinan yang muncul, hal itu bisa menjadi fakta/informasi pernyataan masalah. Siswa menulis pernyataan masalah dengan kata-kata sendiri (seperti yang ditunjukkan pada gambar 2). Pernyataan masalah harus berasal dari analisis kelompok dari apa yang dianggap untuk diketahui dalam menyelesaikan masalah. Pernyataan masalah sering ditinjau kembali dan diedit sebagai informasi yang baru ditemukan, atau informasi yang lama akan dibuang. 

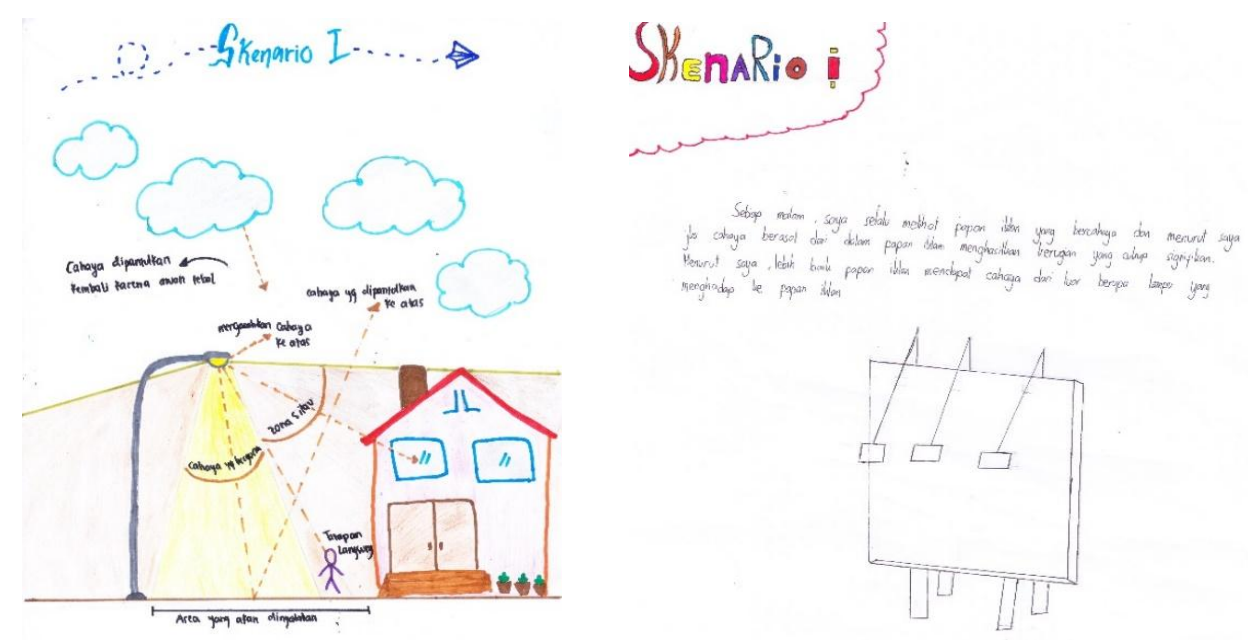

Gambar 3. Memaksimalkan Manfaat dan Kemungkinan Solusi

Dalam skenario 1, siswa dapat mendefinisikan kembali informasi baru menjadi solusi pemecahan masalah. Siswa membuat daftar semua solusi yang mungkin, membuat prioritas dari yang paling kuat hingga paling lemah. Siswa akan memilih solusi yang terbaik, atau yang paling mungkin dapat dilakukan dalam menyelesaikan masalah (seperti yang ditunjukkan pada gambar 3). Skenario 1 adalah bagian memaksimalkan manfaat dan kemungkinan solusi.
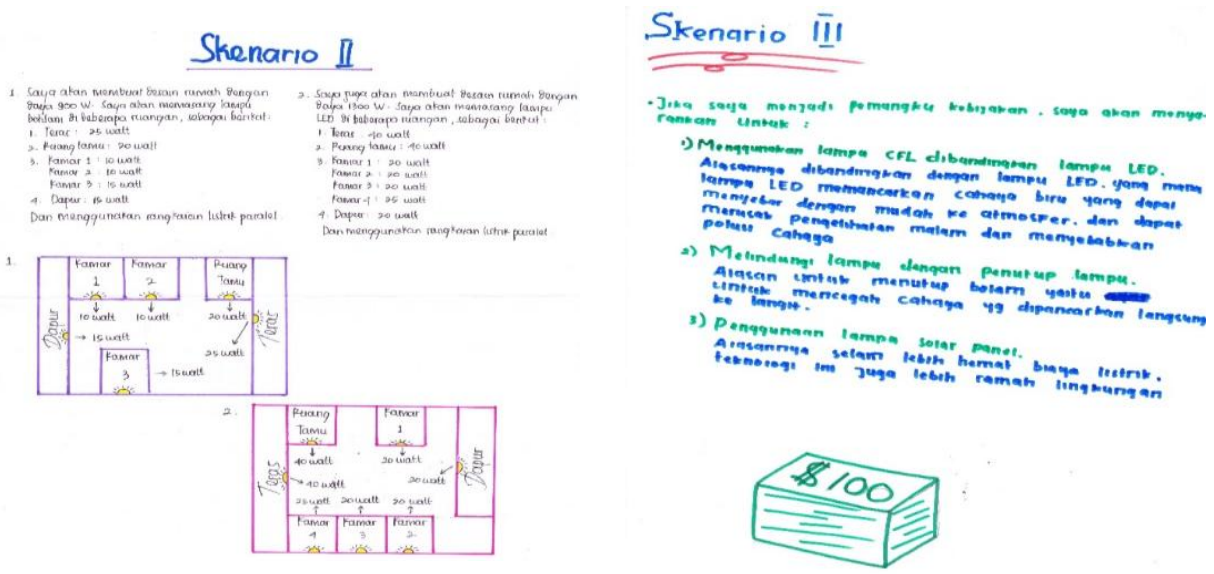

Gambar 4. Berpikir Kreatif dan Problem Solving 
Skenario 2 menunjukkan bahwa siswa dapat belajar mengalami permasalahan yang terjadi dalam kehidupan sehari-hari. Seperti ditunjukkan dalam gambar 4, pengambilan keputusan melibatkan kemampuan memecahkan masalah. Keputusan yang dibuat dengan menganalisis pembahasan pada diskusi kelompok sehingga membuat belajar menjadi bermakna. Siswa berlatih keterampilan komunikasi, dan menunjukkan proses berpikirnya dan berlatih untuk mendapatkan kualitas penilaian yang baik ketika dilakukan penilaian antar teman. Skenario 2 adalah bagian berpikir kreatif dan problem solving. Di bagian ini, siswa juga diminta membuat desain dari permasalahan yang diberikan. Siswa juga akan mengaitkan materi satu dengan materi yang lainnya, misalnya materi cahaya dengan materi listrik, penanaman karakter peduli lingkungan, proses menghitung dan menganalisis dan materi dasar lainnya. Hal ini akan menjadi sebuah sinergisitas antara satu dengan yang lain.

Empat area inti dalam PBL4C yang diharapkan dapat tercapai yakni pengetahuan multi disiplin, keterampilan multi dimensi, pikiran yang tepat dan nilai harmonis universal, merupakan satu kesatuan dan menyeluruh yang harus dilakukan dalam proses pembelajaran. Empat area inti yang muncul dalam penelitian ini yaitu: 1) pengetahuan multi disiplin mencakup sifat-sifat cahaya, pemantulan, pembiasan, cermin datar, pengenalan lingkungan dan pengukuran; 2) pikiran yang tepat mencakup prioritas tugas, pengambilan keputusan, berpikir kreatif, berpikir kritis, merencanakan solusi dalam pemecahan masalah materi pembiasan dan pemantulan sempurna; 3) keterampilan multidimensi mencakup keterampilan mengukur, keterampilan berkomunikasi, kepemimpinan, keterampilan mendengarkan, keterampilan presentasi, keterampilan pemecahan masalah, keterampilan ICT, representasi; 4) nilai harmonis universal mencakup manajemen emosi, manajemen ego, manajemen konflik, kejujuran, kesabaran, rajin, bekerjasama, toleransi, rasa ingin tahu, dan pertimbangan bijaksana.

Dalam situasi ini, pembelajaran kooperatif juga digunakan dalam pembelajaran ini dan membantu untuk mengatasi semua masalah ini (Yaduvanshi, 2015:274). Pembelajaran kooperatif akan mengubah kelas 
besar ke dalam kerjasama kelompok-kelompok kecil (Juweto, 2015:32). Siswa harus memiliki tugas-tugas kooperatif untuk membuat interaksi yang efektif dalam kelompoknya sehingga proses pembelajaran dapat menemukan konsep sendiri (Kulshrestha, 2014:1).

Guru memiliki tanggung jawab untuk mempersiapkan siswa pada masa depan. Meningkatnya sosial, budaya, ekonomi, isu-isu agama dan lingkungan merupakan masalah dalam dunia pendidikan yang harus dipikirkan untuk mempersiapkan generasi muda saat ini. Persiapan tersebut dimulai dari pembelajaran yang dimiliki saat ini. Guru perlu memperbaiki kualitas pembelajaran yang dimiliki saat ini untuk mempersiapkan generasi emas siswa di masa mendatang.

Siswa juga akan membandingkan jawaban serta berinteraksi dengan melakukan diskusi dalam kelompok. Kelompok heterogen yang sudah dibentuk akan membangun keterampilan sosial dan kemampuan dalam berkolaborasi. Hasil diskusi kelompok akan disajikan atau dalam diskusi panel atau klasikal kelas. Dalam tahapan presentasi nantinya, siswa akan menanggapi ataupun mengajukan pertanyaan, serta saling berdiskusi antara satu kelompok dengan kelompok lain.

Hal ini didukung oleh data penelitian. Berdasarkan hasil uji prasyarat yaitu uji normalitas, nilai Kolmogorov-Smirnov untuk tes keterampilan berpikir kritis sebesar 0,131 dengan Asymp. Sig. (2-tailed) sebesar 0,179 dengan nilai $\mathrm{p}>0,05$, sehingga dapat disimpulkan bahwa data yang dianalisis tersebut adalah data yang berdistribusi normal. Hasil uji prasyarat yaitu uji homogenitas menyatakan dari data dua kelompok terlihat bahwa nilai $\mathrm{F}=1.072$ dan nilai $\mathrm{p}>0.05$ (sig. (0.422) $>0.05$ ) ternyata tidak signifikan, sehingga mengandung arti bahwa sebaran data adalah homogen. Berdasarkan uji hipotesis menggunakan T test nilai $\mathrm{p}(.000)<$ 0.05. Dengan kriteria tersebut, $\mathrm{H}_{0}$ ditolak dan $\mathrm{H}_{1}$ diterima. Dengan kata lain, hasil uji menunjukkan bahwa terdapat perbedaan yang signifikan antara keterampilan berpikir kritis siswa dengan pemberian modul PBL4C materi cahaya. Pemberian modul PBL4C materi cahaya dapat meningkatkan hasil keterampilan berpikir kritis siswa. 


\section{Penutup}

Pengembangan modul pembelajaran dengan menggunakan model $4 \mathrm{D}$ yaitu define, design, develop dan dessiminate menghasilkan modul pembelajaran berjudul modul PBL4C. Hasil validasi materi modul adalah 3,31. Hasil validasi desain modul adalah 3,51. Hasil validasi bahasa modul adalah 3,47. Menurut kriteria kevalidan yang telah ditetapkan, materi, desain dan bahasa dalam modul dapat dikatakan valid. Empat area inti dalam PBL4C yang diharapkan dapat tercapai yakni: a) pengetahuan multi disiplin (sifat-sifat cahaya, pemantulan, pembiasan, cermin datar, pengenalan lingkungan dan pengukuran), b) pikiran yang tepat prioritas tugas, pengambilan keputusan, berpikir kreatif, berpikir kritis, merencanakan solusi dalam pemecahan masalah, c) keterampilan multidimensi (keterampilan mengukur, keterampilan berkomunikasi, kepemimpinan, keterampilan mendengarkan, keterampilan presentasi, keterampilan pemecahan masalah, keterampilan ICT, representasi), d) nilai harmonis universal (manajemen emosi, manajemen ego, manajemen konflik, kejujuran, kesabaran, rajin, bekerjasama, toleransi, rasa ingin tahu,bijaksana).

Kelebihan modul PBL4C adalah modul dapat digunakan sebagai sumber belajar siswa, modul yang disusun dapat membimbing siswa dalam menkonstruk/membangun pemahaman dan konsep sendiri pada materi cahaya, modul menyajikan permasalahan kontekstual yang realistik yang sehingga melatih siswa dalam memecahkan masalah. Modul juga dikembangkan dalam aplikasi android sehingga siswa dapat belajar di mana saja, kapan saja, bersama siapa saja. Berdasarkan data penelitian yaitu uji normalitas, dapat disimpulkan bahwa data berdistribusi normal, sebaran data homogen. Berdasarkan uji hipotesis menggunakan T test nilai $\mathrm{p}(.000)<$ 0.05. $\mathrm{H}_{0}$ ditolak dan $\mathrm{H}_{1}$ diterima. Pemberian modul PBL4C materi cahaya dapat meningkatkan hasil keterampilan berpikir kritis siswa.

\section{Ucapan Terimakasih}

Terima kasih disampaikan kepada Bapak Kepala Sekolah SMP Negeri 1 Kraksaan yang telah memberikan fasilitas, kesempatan, dan 
dorongan untuk melakukan penelitian ini. Demikian pula, terima kasih disampaikan kepada teman-teman guru di SMP Negeri 1 Kraksaan yang telah membantu tenaga dan pemikiran sehingga penelitian dan karya tulis ini dapat terwujud dengan baik. Semoga Tuhan Yang Maha Esa memberikan balasan yang setimpal atas budi baik Ibu dan Bapak semua. Aamiin.

\section{Daftar Referensi}

Fuad, N., Zubaidah, S., Susriyati, M., \& Suarsini, E. (2017). Improving Junior High Schools' Critical Thinking Skills Based on Test Three Different Models of Learning. International Journal of Instruction, 10 (1), 101-116

Hussin, N. S. (2018). Industrial Evolution 4.0 and Education. International Journal of Academic Research in Business and Social Sciences. ISSN: 2222-6990, 316-421

Juweto, G. (2015). Effects of Jigsaw Co-Operative Teaching/Learning Strategy and School Location on Students Achievement and Attitude Towards Biology in Secondary School in Delta State. International Journal of Education and Research, 31-40

Kulshrestha, S. (2014). IMplementation of Cooperative Learning in Science: A Development-cum-Experimental Study. Education Research International, 1-7

Mohd Tahjudin, N., \& Chinnappan, M. (2016). The Link between Higher Order Thinking Skills, Representation and Concepts in Enhancing TIMSS Tasks. International Journal of Instruction, 199-214

Pebriana, R. D. (2017). Effect of Problem Based Learning to Critical Thinking Skills Elementary School Students in Social Studies. Journal of Elementary Education, 1(1), 112-182

Preechaporn, W., Tat, T. B., Kin, L. C., \& Kheong, F. H. (2011). ProblemBased Learning the 4 Core Areas (PBL4C): Preparing Childre for the Future. Inspiring Education: Creativity and Entrepreneurship (pp. 1-9). Jakarta Indonesia: 15th UNESCO-APEID International Conference

Yaduvanshi, S. (2015). Cooperative Learning: An Innovative Pedagogy for. International Journal of Applied Research, 274-279 